\title{
Influence of Socio-Economic Conditions of Farmers on the Control of Insect Pests of Citrus in Benue State, Nigeria
}

\author{
T. A. K. Anzaku' ${ }^{1}$ D. A. Anda ${ }^{1} \&$ I. B. $\operatorname{Umar}^{1}$ \\ ${ }^{1}$ College of Agriculture, Lafia, Nasarawa State, Nigeria \\ Correspondence: T. A. K. Anzaku, College of Agriculture, P. M. B. 33, Lafia, Nasarawa State, Nigeria. E-mail: \\ anzakutim@yahoo.com
}

Received: October 29, 2015 Accepted: December 2, 2015 Online Published: January 15, 2016

doi:10.5539/jas.v8n2p84 URL: http://dx.doi.org/10.5539/jas.v8n2p84

\begin{abstract}
Despite the significant losses of citrus fruits due to insect pests damage, not all farmers control the menace of these pests. Control of these pests is inevitable for high quality, sustained and increased production of the product and income for the farmers. It is, therefore, imperative in the study to empirically establish the socio-economic variables of citrus farmers influencing the control of citrus insect pests. To achieve this, data collected from a random sample of 50 commercial citrus farmers from the major producing areas of Benue State in 2014, through the use of questionnaire, were analyzed by employing descriptive statistics and logistic regression model. With the exception of age with a coefficient of -.035, which influenced the control of insect pests negatively, the influence of other variables such as education (.362), experience (.159), gender (.992), income from citrus (.002) and income from other enterprises (.001) were positive, although only education and income earned from citrus were significant at $10 \%$ and $1 \%$ level of probability, respectively. Control of insect pests of citrus can be better achieved by potential and existing farmers if their education and earning from citrus production are continually and simultaneously increased.
\end{abstract}

Keywords: farmers, citrus, control, insect pests, logistic regression

\section{Introduction}

The common species of citrus produced worldwide include grape fruit (Citrus paradisi), sweet orange (Citrus sinensis), lemon (Citrus lemon), lime (Citrus aurantifolia), mandarin/tangelo (Citrus reticulata), pummelo/shaddock (Citrus grandis), sour or Seville orange (Citrus aurantium) and rough lemon (Cobley \& Steele, 1976). Out of the estimated annual world citrus production of over 135 million metric tonnes, 3,800,000 metric tonnes are produced in Nigeria from an estimated land area of 795,000 hectares (FAOSTAT, 2013). Sweet orange is the most widely cultivated species in Nigeria (Umeh, 2008). Citrus is an industrial crop, an important source of food rich in vitamins and minerals, as well as a major source of income for producers. The potential for domestic and export markets of citrus is enormous.

The menace of insect pests and diseases are major threat to the realization of maximum yield of citrus fruits in Nigeria (Umeh, 2008). Of particular economic significance in Nigeria are fruit flies and fruit piercing moths. The females of fruit flies attack citrus by making oviposition holes in the skins of fruits in which they lay their eggs. The feeding of the larvae that emerge on the flesh of the fruits and possible exposure to attack by fungi and bacteria, lead to rotting around the holes and subsequent damage to and premature falling of fruits (Amatobi, 2007). Depending on the severity of damage, yield losses due to fruit flies alone are estimated at between $40 \%$ to 70\% (Umeh, 2004; Amatobi, 2007).

For high yield and quality, competitive domestic and export markets, and consequently high income for farmers, control of insect pests is inevitable. There are already effective chemical, biological and environmentally safe control measures available from research efforts. The implication for control or otherwise of insect pests of citrus, which may have impact on the promotion and sustainability of production and consequently income of the farmers is being addressed in the study. The specific objectives are centred on the socio-economic variables influencing the control of insect pests of citrus.

\section{Methods}

The study area was Benue State. Benue State, which is the leading producer of citrus in Nigeria is located 
between longitude $6^{\circ} 35^{\prime} \mathrm{E}$ and $10^{\circ} \mathrm{E}$, and between latitudes $6^{\circ} 30^{\prime} \mathrm{N}$ and $8^{\circ} 10^{\prime} \mathrm{N}$ (U. M. Ater, P. I. Ater, \& Shima, 2010). In all, 50 out of 115 commercial citrus farmers were randomly selected as respondents from Gboko and Aliade communities noted for producing citrus in large quantities after a reconnaissance survey. The 50 respondents were those with the required information elicited. The others without the necessary data were not used. A questionnaire administered on the respondents, by trained enumerators, was the instrument used for data collection on the socio-economic variables of the farmers, losses of fruits due to fruit pests and the production characteristics for 2014 cropping season in a duration of one month. The analytical tools used were descriptive statistics and logistic regression analysis. The formula used for the logistic regression model is given mathematically in its explicit form as:

Where,

$$
Z=\ln \left(\frac{p}{1-p}\right)=\beta_{0}+\beta_{i} X_{i}+e
$$

$Z=$ Logit, 1 for control, 0 for no control of insect pests;

$p=$ the probability of occurrence, computed as $\frac{\exp ^{\beta_{i}}}{1+\exp ^{\beta_{i}}}$;

$\frac{p_{i}}{1-p}=\log$ odds;

$\ln =$ natural logarithm;

$\beta_{0}=$ constant;

$\beta_{i} X_{i}=$ vector of variables such as age, education, experience, gender, income from citrus and income from other enterprises. Age, education, experience are expressed in years and income in naira;

$\mathrm{e}=$ error term.

Statistical Package for social science (SPSS) was the software used for the analysis.

\section{Results and Discussion}

\subsection{Socio-Economic and Production Characteristics of the Farmers}

The statistics of the socio-economic and production characteristics of citrus farmers are presented in Table 1. The mean values of age (46.74 years), literacy level (11.74 years) and experience (20.34 years) were indications that citrus farmers were relatively young, educated and experienced in citrus production. Age, education, and experience are the personal attributes of the respondents that could affect their responses to production and marketing dynamics. Negative contribution is often expected at very old age and low levels of literacy and experience, while positive contribution is expected at youthful age and high levels of literacy and experience (Olagunju, Adesiyan, \& Ezekiel, 2007; Idiong, 2007). For a tree crop, it is apparent that those at the minimum age and experience groups might have inherited the citrus farms they operated. 
Table 1. Statistics of socio-economic and production characteristics of citrus farmers

\begin{tabular}{|c|c|c|c|c|c|}
\hline \multirow{2}{*}{ Variable } & \multicolumn{5}{|c|}{ Statistics } \\
\hline & Percent & Minimum & Maximum & Mean & Standard deviation \\
\hline Age (years) & & 26.00 & 67.00 & 46.74 & 9.70 \\
\hline Education & & 6.00 & 18.00 & 11.74 & 3.00 \\
\hline Experience (years) & & 5.00 & 46.00 & 20.34 & 9.40 \\
\hline Area of land cultivated (ha.) & & 1.00 & 13.00 & 5.53 & 3.00 \\
\hline Quantity of citrus fruits produced (tons.) & & 7.50 & 1531.26 & 108.73 & 7.14 \\
\hline Quantity of citrus fruits lost to pests (tons.) & & 0.06 & 15.00 & 1.61 & 3.37 \\
\hline Quantity of citrus fruits sold (tons.) & & 7.35 & 1986.54 & 1175.4 & 91.89 \\
\hline Value of citrus fruits sold ( $\mathrm{N} 000)$ & & 735 & 144000 & 44410 & 1032.4 \\
\hline Income from other enterprises ( $₫ 000$ ) & & 17.00 & 76765.00 & 2330.88 & 1295.26 \\
\hline Males & 92 & & & & \\
\hline Females & 8 & & & & \\
\hline Those who controlled insect pests & 80 & & & & \\
\hline Those who did not control insect pests & 20 & & & & \\
\hline
\end{tabular}

The production characteristics - area of land cultivated, quantities of citrus fruits produced, lost to pests, sold and their values - depicted the varying levels of the performance of the predominantly male (92\%) and few female (8\%) farmers in the area. The performance figures indicated that Benue State is one of the leading producers of citrus in Nigeria. For the farmers, income from citrus was comparatively higher than from their other enterprises put together. The mean proportion of about 1.61 metric tonnes lost to pests attack could be attributed to the $20 \%$ of them who did not control pests and those whose control was ineffective.

\subsection{Influence of Socio-Economic Factors on Control of Insect Pests of Citrus}

The analysis of the logistic regression of the variables that influenced the control of insect pests of citrus by farmers are presented in Table 2. Apart from age, which influenced the control of insect pests negatively, the influence of other variables such as education, experience, gender, income from citrus and income from other enterprises were positive, although only education and income earned from citrus were significant at $10 \%$ and $1 \%$ level of probability, respectively. Farmers who had one year increase in their level of education, others variables held constant, were 1.436 times likely to control insect pests of citrus than those who had not. Similarly, if other variables are held constant, farmers who had one naira increase in income realized from citrus were 1.002 times likely to control insect pests of citrus than those who had not. Thus, the probability of the odds in favour of those with one unit increase in education was estimated to be about $59 \%$. Also, the probability of the odds in favour of those with one naira increase in income realized from citrus was estimated to be about $50 \%$. It is clear from the foregoing that both income earned from citrus and level of education are good motivations for controlling insect pests by farmers. Cognizance should be given to these variables in all efforts geared towards improving the quality, output and earnings of citrus farmers in the area. Although the difference per unit for income realized from citrus was just small, this can be important for the sales of large amounts. 
Table 2. Logistic regression analysis of variables influencing the control of insect pests of citrus

\begin{tabular}{llll}
\hline Variable & Coefficient $(\beta)$ & Wald Statistic & Exp $(\beta)$ \\
\hline Constant & -4.345 & 0.920 & 0.013 \\
Age $\left(\beta_{1}\right)$ & -0.035 & 0.166 & 0.966 \\
Education $\left(\beta_{2}\right)$ & 0.362 & 3.096 & $1.436^{* *}$ \\
Experience $\left(\beta_{3}\right)$ & 0.159 & 1.260 & 1.172 \\
Gender $\left(\beta_{4}\right)$ & 0.992 & 0.440 & 2.695 \\
Income from citrus $\left(\beta_{5}\right)$ & 0.002 & 5.529 & $1.002^{*}$ \\
Income from other enterprises $\left(\beta_{6}\right)$ & 0.001 & 0.442 & 1.001 \\
Log likelihood -7.9426 & & & \\
Nagelkerke $\mathrm{R}^{2}=0.035$ & & & \\
\hline
\end{tabular}

Note. ${ }^{*}$ Significant at $1 \%$ level of probability, $* *$ significant at $10 \%$ level of probability.

\section{Conclusion}

Control of insect pests of citrus is necessary for high quality and output of the product. Apart from cost of control, the socio-economic conditions of the farmers also played key roles on the decision of farmers to control insect pests or otherwise. The ultimate desire is for all citrus farmers in all producing states of Benue, Nasarawa, Kogi, Ogun, Oyo, Osun, Ebonyi, Kaduna, Taraba, Ekiti, Imo, Kwara, Edo and Delta to control insect pests for maximum economic benefits.

\section{References}

Amatobi, C. I. (2007). Arthropod pests of crops in Nigeria: General biology, natural enemies and control. P. A. Ndahi Printing, Zaria, Nigeria.

Ater, U. M., Ater, P. I., \& Shima, M. (2010). An assessment of the National Special Programme for Food Security in Benue State, Nigeria. Journal of Rural Development, Agriculture and Science, 1(1), 126-136.

Cobley, L. S., \& Steele, W. M. (1976). An introduction to the Botany of tropical crops. Longman, New York.

Idiong, I. C. (2007). Estimation of farm level efficiency in small-scale swamp rice production in Cross River State of Nigeria: A stochastic Frontier approach. World Journal of Agricultural Science, 3(5), 653-658.

FAOSTAT. (2013). Retrieved September 15, 2015, from http://www.factfish.com

Olagunju, F. I., Adesiyan, I. O., \& Ezekiel, A. A. (2007). Economic viability of catfish in Oyo State. Nigeria Journal of Human Ecology, 21(2), 121-124.

Umeh, V. C., Olaniyan, A. A., Ker, \& Andir, J. (2004). Development of citrus fruit fly control strategies for smallholders in Nigeria. Fruits, 59, 265-267. http://dx.doi.org/10.1051/fruits:2004025

Umeh, V. C., Garcia, L. E., \& Meyer, M. D. (2008). Fruit flies of citrus in Nigeria: Species of diversity, relative abundance and spread in major producing areas. Fruit, 63, 145-153. http://dx.doi.org/10.1051/fruits:2008004

\section{Copyrights}

Copyright for this article is retained by the author(s), with first publication rights granted to the journal.

This is an open-access article distributed under the terms and conditions of the Creative Commons Attribution license (http://creativecommons.org/licenses/by/3.0/). 